\title{
Genome sequence and description of Bacteroides timonensis sp. nov.
}

\author{
Dhamodharan Ramasamy ${ }^{1}$, Jean-Christophe Lagier ${ }^{1}$, Morgane Rossi-Tamisier ${ }^{1}$, Anne \\ Pfleiderer $^{1}$, Caroline Michelle ${ }^{1}$, Carine Couderc ${ }^{1}$, Didier Raoult ${ }^{1,2}$ and Pierre-Edouard \\ Fournier $^{1 *}$ \\ ${ }^{1}$ Unité de Recherche sur les Maladies Infectieuses et Tropicales Emergentes, Institut \\ Hospitalo-Universitaire Méditerranée-Infection, Faculté de médecine, Aix-Marseille \\ Université, Marseille, France \\ ${ }^{2}$ King Fahd Medical Research Center, King Abdul Aziz University, Jeddah, Saudi Arabia \\ *Correspondence: Pierre-Edouard Fournier (pierre-edouard.fournier@univ-amu.fr)
}

Keywords: Bacteroides timonensis, genome, culturomics, taxono-genomics

\begin{abstract}
Bacteroides timonensis strain $\mathrm{AP}^{\top}{ }^{\top}$ (= CSUR P194 = DSM 26083) is the type strain of $B$. timonensis sp. nov. This strain, whose genome is described here, was isolated from the fecal flora of a 21-year-old French Caucasoid female who suffered from severe anorexia nervosa. Bacteroides timonensis is a Gram-negative, obligate anaerobic bacillus. Here we describe the features of this organism, together with the complete genome sequence and annotation. The 7,130,768 bp long genome (1 chromosome, no plasmid) exhibits a $\mathrm{G}+\mathrm{C}$ content of $43.3 \%$ and contains 5,786 protein-coding and 59 RNA genes, including 2 rRNA genes.
\end{abstract}

\section{Introduction}

Bacteroides timonensis strain AP1 ${ }^{\mathrm{T}}$ (= CSUR P194 = DSM 26083) is the type strain of B. timonensis sp. nov. This bacterium was isolated from the stool sample of a 21-year-old French Caucasoid female in an effort of cultivating individually all bacterial species within human feces [1]. It is a Gram-negative, anaerobic, indole-positive rodshaped bacillus.

The conventional genetic parameters used in the delineation of bacterial species include $16 \mathrm{~S}$ rRNA sequence identity and phylogeny $[2,3]$, genomic $\mathrm{G}+\mathrm{C}$ content diversity and DNA-DNA hybridization (DDH) $[4,5]$. These tools have limitations, notably because their cutoff values vary across species or genera [6]. With the introduction of high-throughput sequencing techniques [7], a wealth of genomic data was made available for many bacterial species. We recently proposed to include genomic data in a polyphasic approach to describe new bacterial taxa (taxono-genomics) [8]. This strategy combines phenotypic characteristics, notably the MALDITOF MS spectrum, and genomic analysis [8-37].

Here, we present a summary classification and a set of features for $B$. timonensis sp. nov. strain AP1 $^{\mathrm{T}}$ (= CSUR P194 = DSM 26083) together with the description of the complete genome sequencing and annotation. These characteristics support the circumscription of the type species, B. timonensis.

The genus Bacteroides (Castellani and Chalmers 1919) was created in 1919 [38]. Currently, it is one of the largest genera among the human gut microbiota [39], and consists of 91 species and 5 subspecies with validly published names [40]. Bacteroides species are Gram-negative, nonspore-forming, non-motile and anaerobic rods that are generally isolated from the gastrointestinal tract of mammals [41]. They have symbiotic relationships with humans and play many beneficial roles on normal intestinal physiology and function. Several Bacteroides species are identified as opportunistic pathogens when isolated from anaerobic infections [42].

\section{Classification and features}

A stool sample was collected from 21-year-old French Caucasoid female who suffered from severe restrictive anorexia nervosa from the age of 12 years. At the time of sample collection, she had been hospitalized for recent aggravation of her medical condition (BMI: $10.4 \mathrm{~kg} / \mathrm{m}^{2}$ ). The patient's written consent and the agreement of the local ethics committee of the IFR48 (Marseille, France) were obtained under agreement number 09-022. The feces sample of this patient 
was stored at $-80^{\circ} \mathrm{C}$ immediately after collection. Strain $\mathrm{AP} 1^{\mathrm{T}}$ (Table 1) was isolated in November 2011 after 1 month of incubation in Columbia agar (BioMerieux, Marcy l'Etoile, France). Several other new bacterial species were isolated from this stool specimen using various culture conditions.

When compared to sequences available in GenBank, the 16S rRNA gene sequence of $B$. timonensis strain AP1 $1^{\mathrm{T}}$ (GenBank accession number JX041639) exhibited an identity of
97.00\% with Bacteroides cellulosilyticus (Figure 1). This value was the highest similarity observed, but was lower than the $97.8 \% 16 \mathrm{~S}$ rRNA gene sequence threshold recommended by Stackebrandt and Ebers (2006) to delineate a new species without carrying out DNA-DNA hybridization [3], and was in the 74.8 to $98.7 \%$ range of $16 \mathrm{~S}$ rRNA identity values observed among 41 Bacteroides species with validly published names [56].

Table 1. Classification and general features of Bacteroides timonensis strain $A P 1^{\top}$ according to the MIGS recommendations [43]

\begin{tabular}{|c|c|c|c|}
\hline MIGS ID & Property & Term & Evidence code $^{\mathrm{a}}$ \\
\hline & Current classification & Domain Bacteria & TAS [44] \\
\hline & & Phylum Bacteroidetes & TAS $[45,46]$ \\
\hline & & Class Bacteroidia & TAS $[45,47]$ \\
\hline & & Order Bacteroidales & TAS $[45,48]$ \\
\hline & & Family Bacteroidaceae & TAS $[49,50]$ \\
\hline & & Genus Bacteroides & IDA $[49,51-54]$ \\
\hline & & Species Bacteroides timonensis & IDA \\
\hline & & Type strain $\mathrm{AP} 1^{\top}$ & IDA \\
\hline & Gram stain & Negative & IDA \\
\hline & Cell shape & Rod & IDA \\
\hline & Motility & Non motile & IDA \\
\hline & Sporulation & Non sporulating & IDA \\
\hline & $\begin{array}{l}\text { Temperature range } \\
\text { Optimum tempera- } \\
\text { ture }\end{array}$ & $\begin{array}{l}\text { Mesophile } \\
37^{\circ} \mathrm{C}\end{array}$ & $\begin{array}{l}\text { IDA } \\
\text { IDA }\end{array}$ \\
\hline MIGS-6.3 & Salinity & Unknown & IDA \\
\hline \multirow[t]{3}{*}{ MIGS-22 } & Oxygen requirement & Anaerobic & IDA \\
\hline & Carbon source & Unknown & IDA \\
\hline & Energy source & Unknown & IDA \\
\hline MIGS-6 & Habitat & Human gut & IDA \\
\hline MIGS-14 & $\begin{array}{l}\text { Biotic relationship } \\
\text { Pathogenicity } \\
\text { Biosafety level } \\
\text { Isolation }\end{array}$ & $\begin{array}{l}\text { Free living } \\
\text { Unknown } \\
2 \\
\text { Human feces }\end{array}$ & IDA \\
\hline MIGS-4 & $\begin{array}{l}\text { Geographic location } \\
\text { Sample collection }\end{array}$ & France & IDA \\
\hline MIGS-5 & time & November 2011 & IDA \\
\hline MIGS-4.1 & Latitude & 43.296482 & IDA \\
\hline MIGS-4.1 & Longitude & 5.36978 & IDA \\
\hline MIGS-4.3 & Depth & surface & IDA \\
\hline MIGS-4.4 & Altitude & $0 \mathrm{~m}$ above sea level & IDA \\
\hline
\end{tabular}

Evidence codes - IDA: Inferred from Direct Assay; TAS: Traceable Author Statement (i.e., a direct report exists in the literature); NAS: Non-traceable Author Statement (i.e., not directly observed for the living, isolated sample, but based on a generally accepted property for the species, or anecdotal evidence). These evidence codes are from the Gene Ontology project [55]. If the evidence is IDA, then the property was directly observed for a live isolate by one of the authors or an expert mentioned in the acknowledgements. 


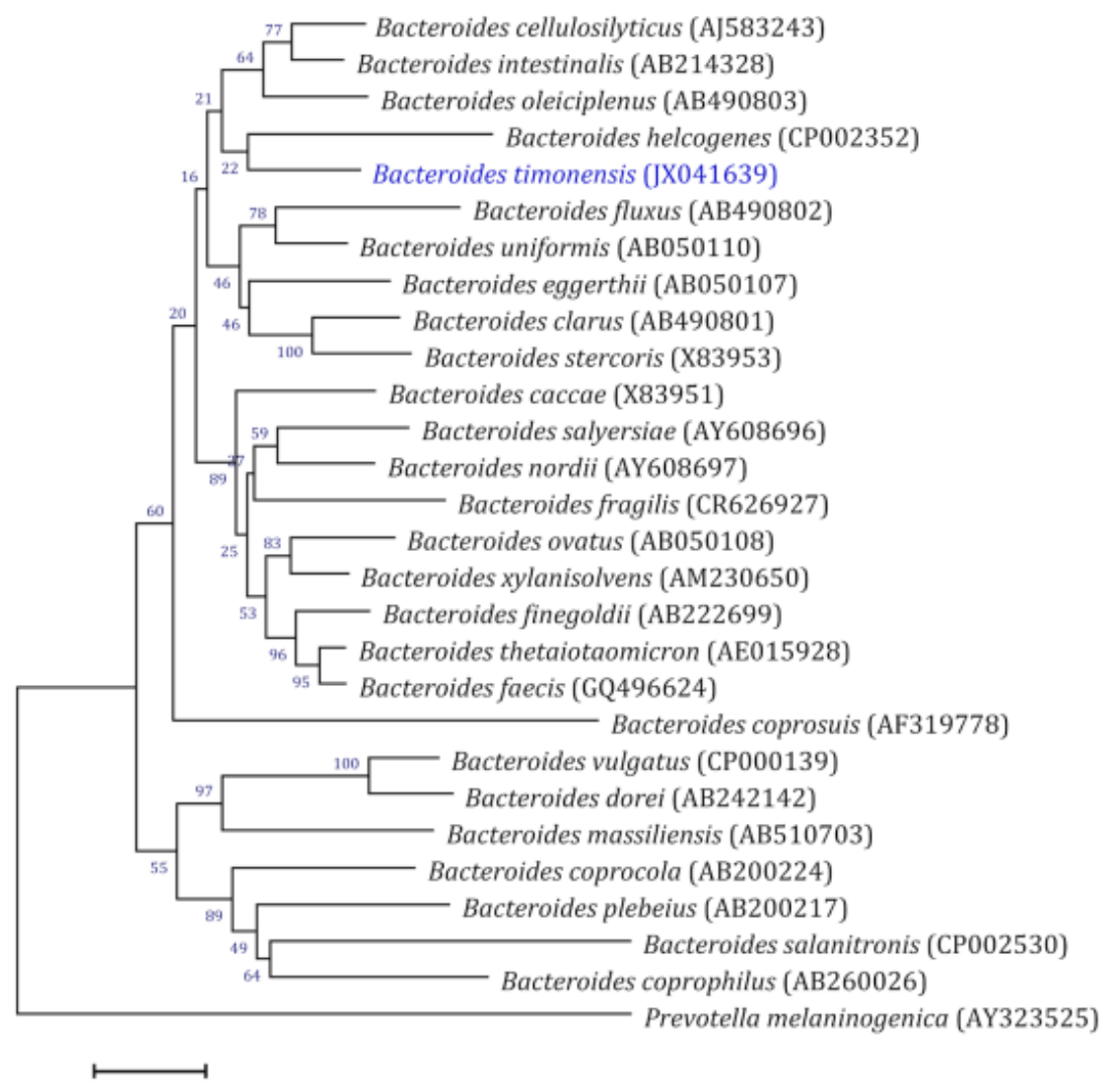

Figure 1. Phylogenetic tree highlighting the position of Bacteroides timonensis strain $\mathrm{AP}^{\top}{ }^{\top}$ relative to other type strains within the Bacteroides genus. GenBank accession numbers are indicated in parentheses. Sequences were aligned using CLUSTALW, and phylogenetic inferences were obtained using the maximum-likelihood method within the MEGA software. Numbers at the nodes are percentages of bootstrap values obtained from 500 replicates. Prevotella melaninogenica was used as outgroup. The scale bar represents a $2 \%$ nucleotide sequence divergence.

Four different growth temperatures $(25,30,37$, $45^{\circ} \mathrm{C}$ ) were tested; growth occurred between 25 and $37^{\circ} \mathrm{C}$, but optimal growth was observed at $37^{\circ} \mathrm{C}, 24$ hours after inoculation. No growth occurred at $45^{\circ} \mathrm{C}$. Colonies were translucent and approximately $0.3 \mathrm{~mm}$ in diameter on $5 \%$ sheep blood-enriched Columbia agar (BioMerieux). Growth of the strain was tested in the same agar under anaerobic and microaerophilic conditions using GENbag anaer and GENbag microaer systems, respectively (BioMerieux), and under aerobic conditions, with or without $5 \% \mathrm{CO}_{2}$. Growth was observed under anaerobic and microaerophilic conditions, and only weakly with $5 \% \mathrm{CO}_{2}$. No growth occurred under aerobic condition without $\mathrm{CO}_{2}$. Gram staining showed short Gram-negative rods unable to form spores (Figure 1). A motility test was negative. Cells grown on agar are translucent and exhibit a mean diameter of $0.88 \mu \mathrm{m}$ in electron microscopy (Figure 2, Figure 3).

Strain AP1 $1^{\mathrm{T}}$ exhibited catalase but no oxidase activity (Table 2). Using an API Rapid ID 32A strip (BioMerieux), positive reactions were obtained for arginine dihydrolase, $\alpha$-galactosidase, $\beta$ galactosidase, $\alpha$-glucosidase, $\beta$-glucosidase, $\alpha$ arabinosidase, $\mathrm{N}$-acetyl- $\beta$-glucosaminidase, glutamic acid decarboxylase, $\alpha$-fucosidase, nitrate reduction, indole production, alkaline phosphatase, proline arylamidase, leucyl glycine arylamidase, alanine arylamidase, glutamyl glutamic acid arylamidase, and fermentation of mannose and raffinose. Weak activities were observed for glycine arylamidase and serine arylamidase. Negative reactions were obtained for urease, $\beta$-galctosidase-6-phosphatase, $\beta$ glucuronidase, arginine arylamidase, phenylalanine arylamidase, leucine arylamidase, pyroglutamic acid arylamidase, tyrosine arylamidase and histidine arylamidase. Using an API 50CH strip (Biomerieux), strain AP1 ${ }^{\mathrm{T}}$ was asaccharolytic. B. timonensis is susceptible to amoxicillin-clavulanate, ceftriaxon, imipenem, trimethoprim-sulfamethoxazole, metronidazole and doxycycline but resistant to amoxicillin, vancomycin and gentamicin. By comparison with other Bacteroides species, B. timonensis dif- 
fered in production of indole, nitrate reductase,

$\beta$-galactosidase and acidification of sugars.



Figure 2. Gram staining of $B$. timonensis strain $\mathrm{AP} 1^{\mathrm{T}}$

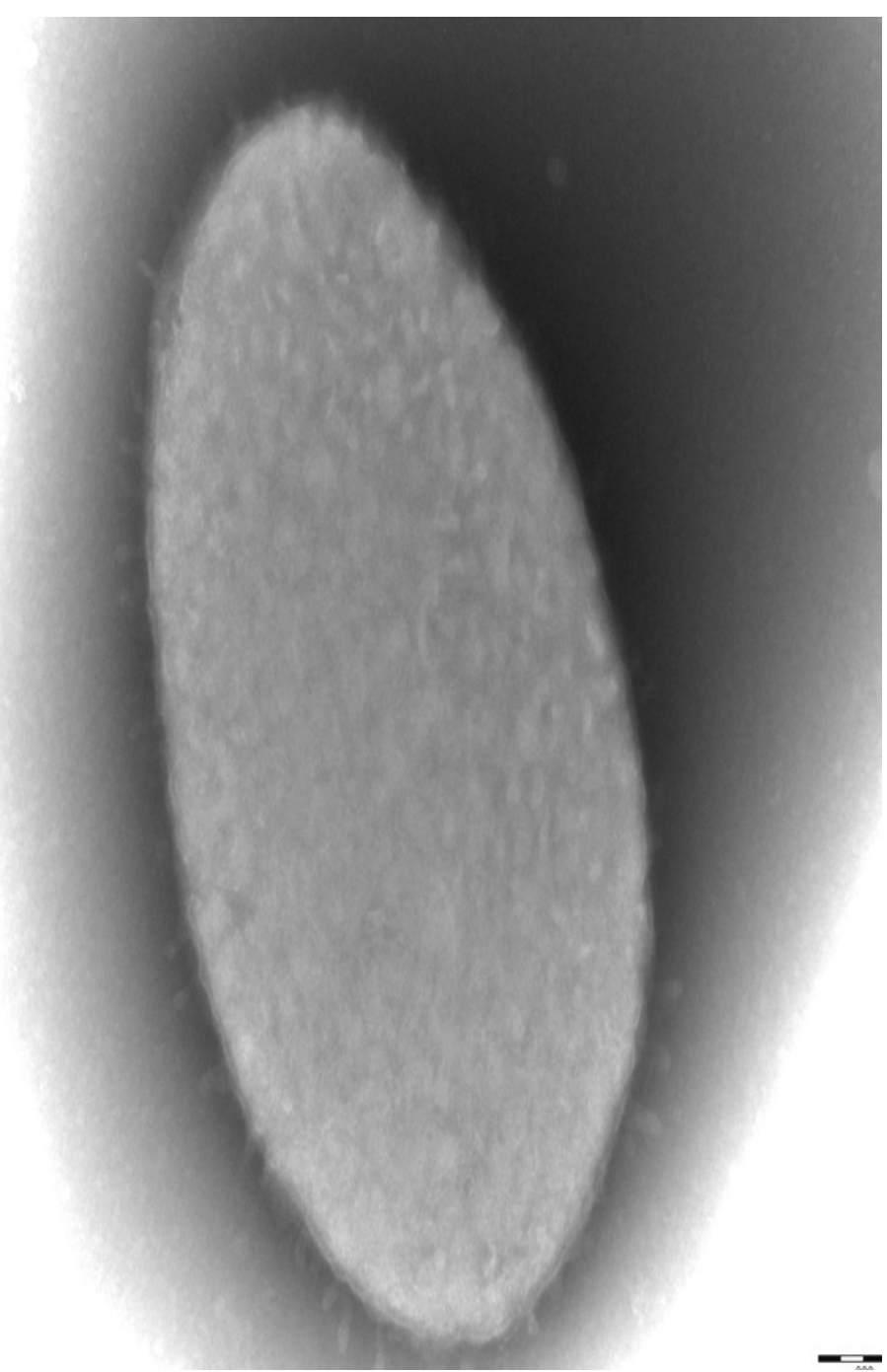

Figure 3. Transmission electron microscopy of $B$. timonensis strain $\mathrm{AP}^{\top}{ }^{\top}$, made using a Morgani $268 \mathrm{D}$ (Philips) at an operating voltage of $60 \mathrm{kV}$. The scale bar represents $200 \mathrm{~nm}$ 


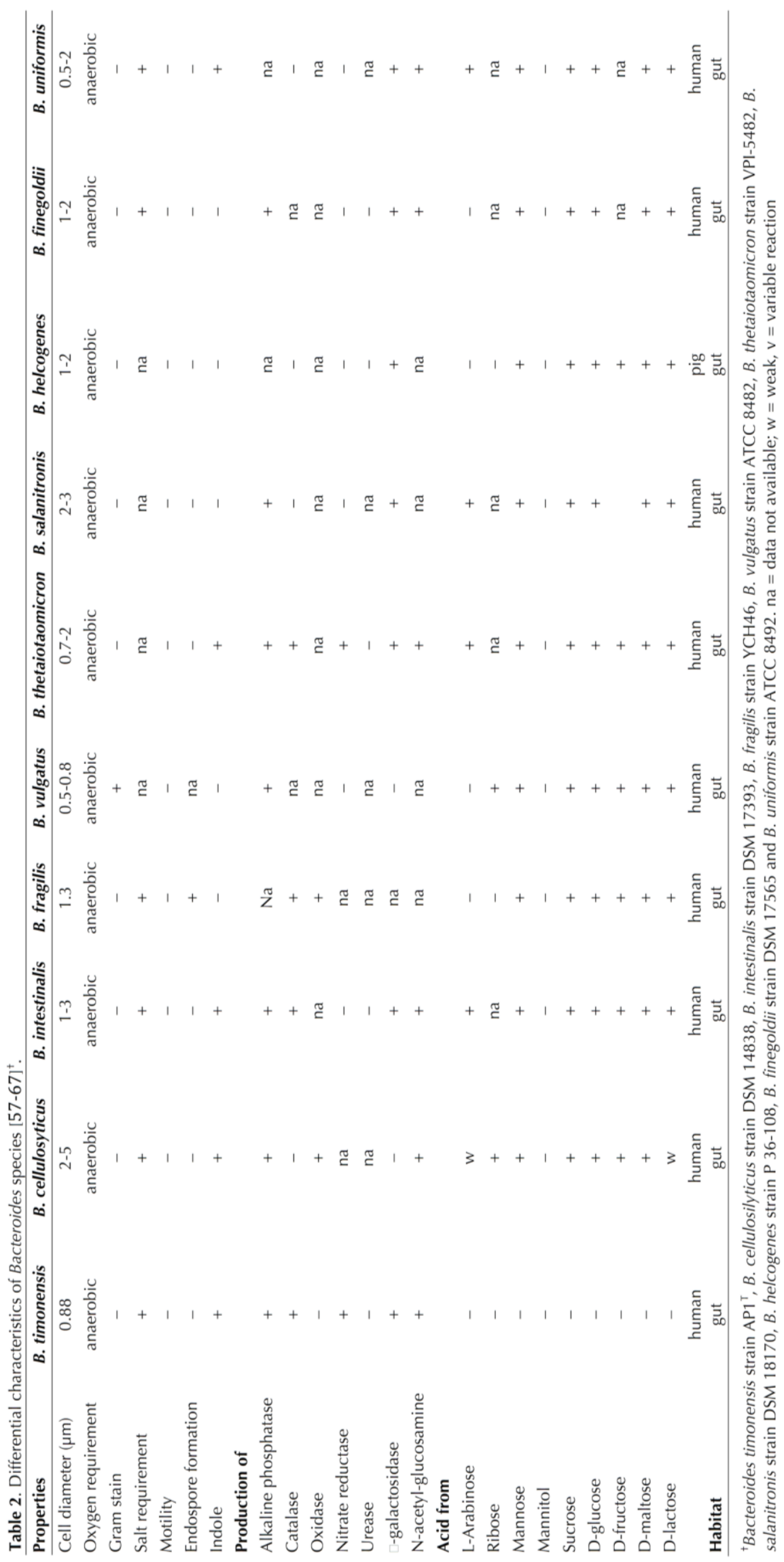


Matrix-assisted laser-desorption/ionization time-of-flight (MALDI-TOF) MS protein analysis was carried out as previously described [68]. Briefly, a pipette tip was used to pick one isolated bacterial colony from a culture agar plate and spread it as a thin film on a MTP 384 MALDITOF target plate (Bruker Daltonics, Leipzig, Germany). Twelve distinct deposits from twelve isolated colonies were performed for strain $A P 1^{\mathrm{T}}$. Each smear was overlaid with $2 \mu \mathrm{L}$ of matrix solution (saturated solution of alpha-cyano4-hydroxycinnamic acid) in 50\% acetonitrile, $2.5 \%$ tri-fluoracetic acid, and allowed to dry for 5 minutes. Measurements were performed with a Microflex spectrometer (Bruker). Spectra were recorded in the positive linear mode for the mass range of 2,000 to $20,000 \mathrm{Da}$ (parameter settings: ion source 1 (ISI), 20kV; IS2, $18.5 \mathrm{kV}$; lens, $7 \mathrm{kV}$ ). A spectrum was obtained after 675 shots with variable laser power. The time of acquisition was between 30 seconds and 1 minute per spot. The twelve $\mathrm{AP} 1^{\mathrm{T}}$ spectra were import- ed into the MALDI BioTyper software (version 2.0, Bruker) and analyzed by standard pattern matching (with default parameter settings) against the main spectra of 3,769 bacteria, including 129 spectra from 98 Bacteroides species. The method of identification included the $\mathrm{m} / \mathrm{z}$ from 3,000 to 15,000 Da. For every spectrum, a maximum of 100 peaks were compared with spectra in database. The resulting score enabled the identification of tested species, or not: a score $\geq 2$ with a validly published species enabled identification at the species level, a score $\geq$ 1.7 but $<2$ enabled identification at the genus level, and a score $<1.7$ did not enable any identification. No significant MALDI-TOF score was obtained for strain $\mathrm{AP} 1^{\mathrm{T}}$ against the Bruker database, suggesting that our isolate was not a member of a known species. We added the spectrum from strain AP1T to our database (Figure 4). Finally, the gel view showed the spectral differences with other members of the genus Bacteroides (Figure 5).

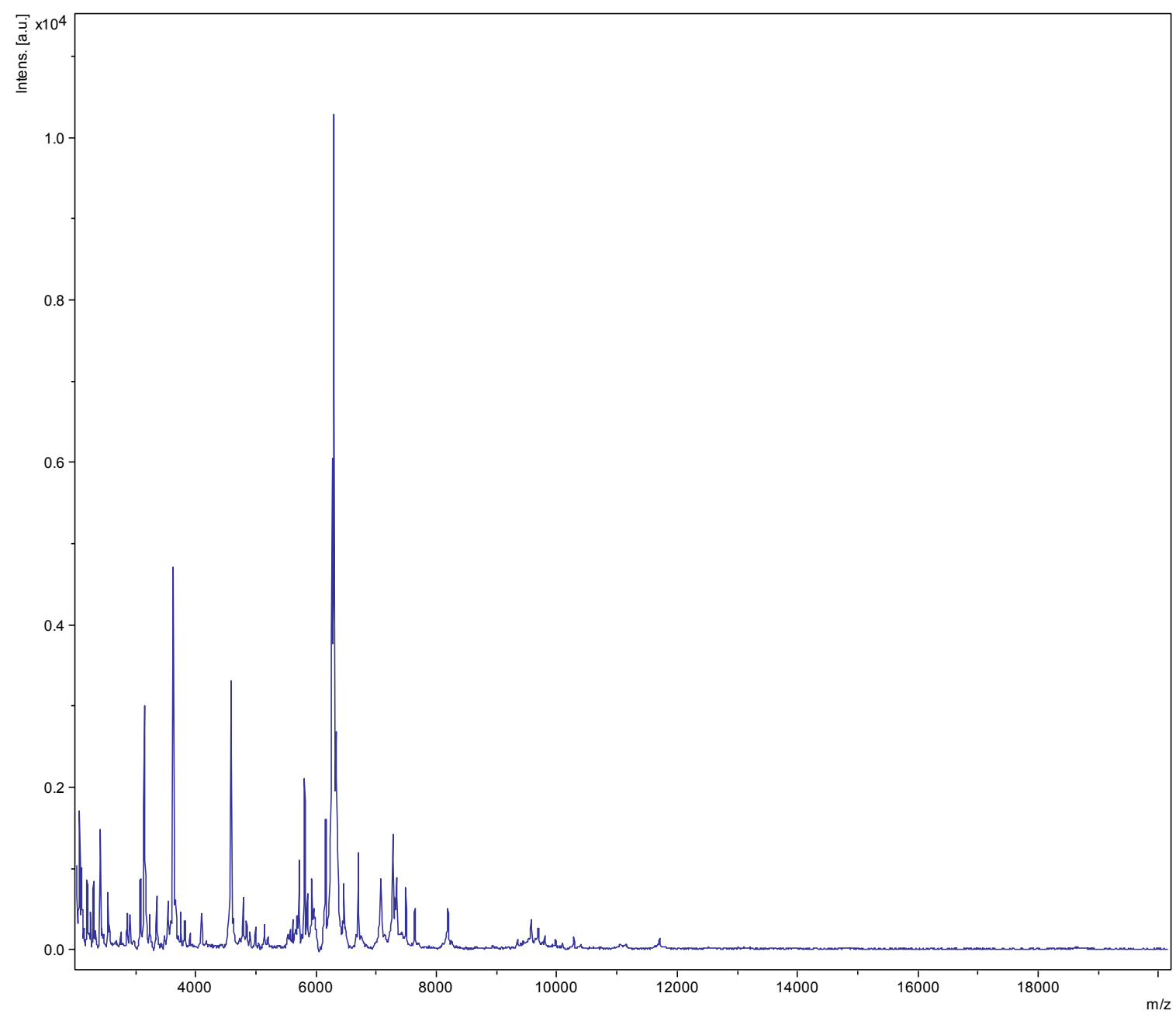

Figure 4. Reference mass spectrum from $B$. timonensis strain $\mathrm{AP}^{\top}{ }^{\top}$. Spectra from 12 individual colonies were compared and a reference spectrum was generated. 
Bacteroides vulgatus DSM 1447T Bacteroides ureolyticus DSM 20703T Bacteroides unif ormis DSM 6597T Bacteroides timonensis

Bacteroides thetaiotaomicron DSM 2079T Bacteroides stercoris DSM $19555 T$ Bacteroides salyersiae DSM 18765T Bacteroides ov atus DSM 1896 T Bacteroides nordii DSM 18764T Bacteroides massiliensis DSM 17679T Bacteroides intestinalis DSM 173937 Bacteroides heparinolyticus 9208882 Bacteroides gallinarum DSM 18171T Bacteroides fragilis DSM 9669 Bacteroides finegoldii DSM $17565 T$ Bacteroides eggerthii DSM 20697T Bacteroides cellulosilyticus 10069242 Bacteroides caccae DSM $19024 T$

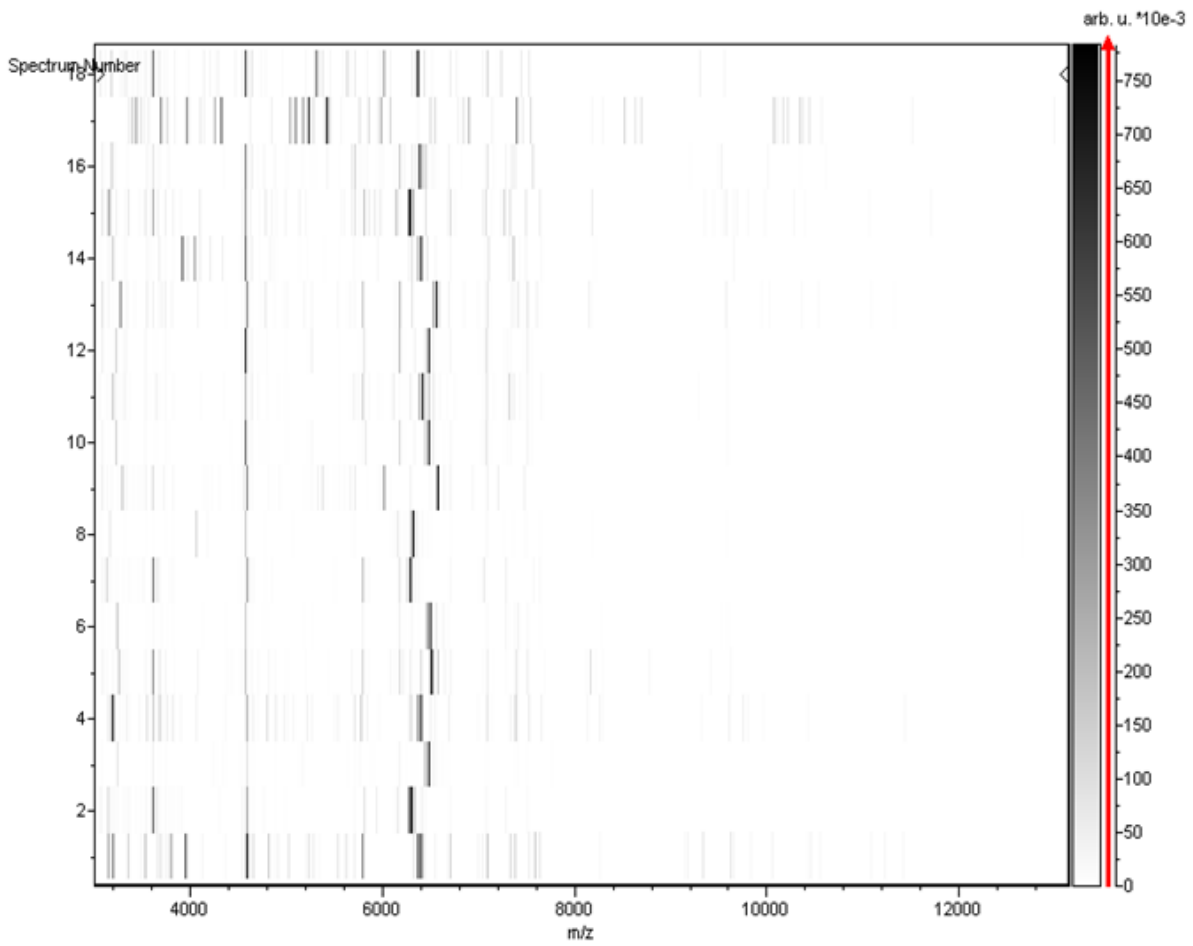

Figure 5. Gel view comparing $B$. timonensis strain $\mathrm{AP} 1^{\top}$ to other Bacteroides species. The gel view displays the raw spectra of loaded spectrum files as a pseudo-electrophoretic gel. The $x$-axis records the $\mathrm{m} / \mathrm{z}$ value. The left $y$-axis displays the running spectrum number originating from subsequent spectra loading. The peak intensity is expressed by a grey scale scheme code. The grey scale bar on the right $y$-axis indicate the relation between the shade of grey a peak is displayed with and the peak intensity in arbitrary units. Displayed species are detailed in the left column.

\section{Genome sequencing information} Genome project history

The organism was selected for sequencing on the basis of its phylogenetic position and $16 \mathrm{~S}$ rRNA gene sequence similarity to members of the genus Bacteroides, and is part of a study of the human digestive flora aiming at isolating all bacterial species within human feces [1]. It was the ninety-ninth genome of a Bacteroides species and the first genome of $B$. timonensis sp. nov. The GenBank accession number is CBVI000000000 and consists of 211 contigs. Table 3 shows the project information and its association with MIGS version 2.0 compliance [43].

Table 3. Project information

\begin{tabular}{lll}
\hline MIGS ID & Property & Term \\
\hline MIGS-31 & Finishing quality & High-quality draft \\
MIGS-28 & Libraries used & 454 GS paired-end 3-kb library \\
MIGS-29 & Sequencing platform & 454 GS FLX Titanium \\
MIGS-31.2 & Fold coverage & 35.76 \\
MIGS-30 & Assemblers & gsAssembler \\
MIGS-32 & Gene calling method & PRODIGAL \\
\hline
\end{tabular}

\section{Growth conditions and DNA isolation}

B. timonensis sp. nov., strain AP1 ${ }^{\mathrm{T}}$ (= CSUR P194 = DSM 26083) was grown on 5\% sheep bloodenriched Columbia agar (BioMerieux) at $37^{\circ} \mathrm{C}$ in anaerobic atmosphere. Bacteria grown on four
Petri dishes were harvested and resuspended in $4 \times 100 \mu \mathrm{L}$ of TE buffer. Then, $200 \mu \mathrm{L}$ of this suspension was diluted in $1 \mathrm{ml}$ TE buffer for lysis treatment that included a 30 - minute incubation with $2.5 \mu \mathrm{g} / \mu \mathrm{L}$ lysozyme at $37^{\circ} \mathrm{C}$, followed by an 
overnight incubation with $20 \mu \mathrm{g} / \mu \mathrm{L}$ proteinase $\mathrm{K}$ at $37^{\circ} \mathrm{C}$. Extracted DNA was then purified using 3 successive phenol-chloroform extractions and ethanol precipitation at $-20^{\circ} \mathrm{C}$ overnight. After centrifugation, the DNA was resuspended in $160 \mu \mathrm{L}$ TE buffer. The yield and concentration was measured by the Quant-it Picogreen kit (Invitrogen) on the Genios-Tecan fluorometer at $88.6 \mathrm{ng} / \mu \mathrm{l}$.

\section{Genome sequencing and assembly}

Five $\mu \mathrm{g}$ of DNA was mechanically fragmented on Covaris device (KBioScience-LGC Genomics, Teddington, UK) using miniTUBE-blue. The DNA fragmentation was visualized through an Agilent 2100 BioAnalyzer on a DNA labchip 7500 with an average size of $2.950 \mathrm{~kb}$. A $3 \mathrm{~kb}$ paired-end library was constructed according to the 454 GS FLX Titanium paired-end protocol (Roche). Circularization and nebulization were performed and generated a pattern with a mean size of 513 bp. After PCR amplification through 17 cycles followed by double size selection, the single stranded paired-end library was quantified with the Quant-it Ribogreen kit (Invitrogen) on the Genios Tecan fluorometer at $243 \mathrm{pg} / \mu \mathrm{L}$. The library concentration equivalence was calculated as $8.69 \times 10^{8}$ molecules/ $\mu \mathrm{L}$. The library was stored at $-20^{\circ} \mathrm{C}$ until further use.

The paired-end library was clonally amplified with $0.5 \mathrm{cpb}$ and $1 \mathrm{cbp}$ in $8 \mathrm{SV}$-emPCR reactions with the GS Titanium SV emPCR Kit (Lib-L) v2 (Roche). The yields of the emPCR reactions were 4.65 and $7.29 \%$ respectively, within the recommended range of 5 to $20 \%$ from the Roche procedure. Approximately 790,000 beads were loaded on a $1 / 4$ region of a GS Titanium PicoTiterPlate PTP Kit $70 \times 75$ and sequenced with the GS Titanium Sequencing Kit XLR70 (Roche). The run was performed overnight and then analyzed on the cluster through the gsRunBrowser and Newbler assembler (Roche). A total of 802,249 passed filter wells were obtained and generated $255 \mathrm{Mb}$ with a length average of $314 \mathrm{bp}$. These sequences were assembled using Newbler (Roche) with 90\% identity and $40 \mathrm{bp}$ as overlap. The final assembly identified 63 scaffolds and 211 large contigs (>1,500bp) generating a genome size of $7.13 \mathrm{Mb}$ which corresponds to a coverage of $35.76 \times$ genome equivalent.

\section{Genome annotation}

Open Reading Frames (ORFs) were predicted using Prodigal [69] with default parameters. However, the predicted ORFs were excluded if they spanned a sequencing gap region. The predicted bacterial protein sequences were searched against the GenBank [70] and Clusters of Orthologous Groups (COG) databases using BLASTP. The tRNAs and rRNAs were predicted using the tRNAScan-SE [71] and RNAmmer [72] tools, respectively. Signal peptides and numbers of transmembrane helices were predicted using SignalP [73] and TMHMM [74], respectively. Mobile genetic elements were predicted using PHAST [75] and RAST [76]. ORFans were identified if their BLASTP $E$-value was lower than $1 \mathrm{e}$ 03 for alignment length greater than 80 amino acids. If alignment lengths were smaller than 80 amino acids, we used an $E$-value of 1e-05. Such parameter thresholds have already been used in previous works to define ORFans. Artemis [77] and DNA Plotter [78] were used for data management and visualization of genomic features, respectively. The Mauve alignment tool (version 2.3.1) was used for multiple genomic sequence alignment [79].

To estimate the mean level of nucleotide sequence similarity at the genome level between $B$. timonensis and 9 other members of the genus Bacteroides (Table 6), we used the Average Genomic Identity of gene Sequences (AGIOS) inhouse software [8]. Briefly, this software uses the Proteinortho software [80] for the pairwise detection of orthologous proteins between genomes, then retrieves the corresponding genes and determines the mean percentage of nucleotide sequence identity among orthologous ORFs using the Needleman-Wunsch global alignment algorithm. B. timonensis strain AP1T was compared to $B$. intestinalis strain DSM 17393 (GenBank accession number NZ_ABJL00000000), B. cellulosilyticus strain DSM 14838 (NZ_ACCH00000000), B. fragilis strain YCH46 (NC_006347), B. vulgatus strain ATCC 8482 (NC_009614), B. thetaiotaomicron strain VPI-5482 (NC_004663), B. salanitronis strain DSM 18170 (NC_015164), B. helcogenes strain P36-108 (NC_014933), B. finegoldii strain DSM 17565 (NZ_ABXI00000000) and $B$. uniformis strain ATCC 8492 (AAYH00000000).

\section{Genome properties}

The genome is 7,130,768 bp long ( 1 chromosome, but no plasmid) with a $43.3 \% \mathrm{G}+\mathrm{C}$ content (Figure 6 and Table 4). Of the 5,845 predicted genes, 5,786 were protein-coding genes and 59 were RNAs, including 1 complete rRNA operon. A total of 3,111 genes $(53.22 \%)$ were assigned a putative function and 3,283 genes were identified as ORFans (56.16\%). Strain AP1 ${ }^{\mathrm{T}}$ possesses a variety of mobile genetic elements. These include 6 prophages of $13.70,14.60,10.51,8.18$, 9.91 and $12.79 \mathrm{~Kb}$, respectively) and 91 trans- 
posable elements belonging to 18 transposon families that include the putative mobilization protein BF0133, the putative conjugative transposon mobilization protein BF0132, the hypothetical protein clustered with conjugative transposons BF0131, TraA-CTn, TraB-CTn,TraDCTn,TraE-CTn,TraF-CTn,TraG-CTn,TraH-
CTn,TraI-CTn,TraJ-CTn,TraK-CTn,TraL-

CTn,TraM-CTn,TraN-CTn,TraO-CTn and TraQCTn. The properties and statistics of the genome are summarized in Tables 4 and 5. The distribution of genes into COGs functional categories is presented in Table 5.

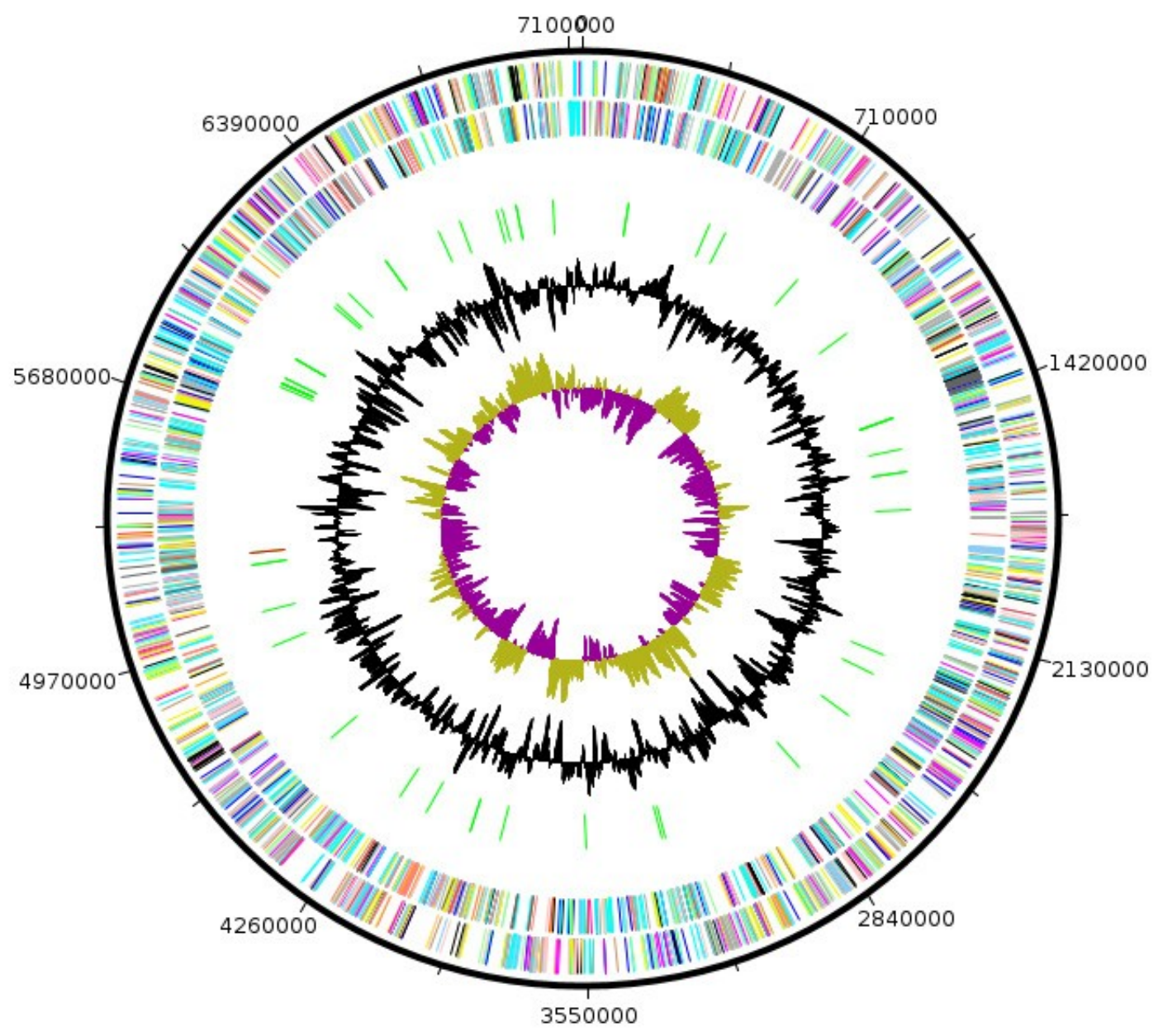

Figure 6. Graphical circular map of the chromosome. From the outside in: open reading frames oriented in the forward (colored by COG categories) direction, open reading frames oriented in the reverse (colored by COG categories) direction, RNA operon (red), and tRNAs (green), GC content plot, and GC skew (purple: negative values, olive: positive values).

Table 4. Nucleotide content and gene count levels of the genome

\begin{tabular}{lrr}
\hline Attribute & Value & \% of tota $^{\mathbf{a}}$ \\
\hline Genome size (bp) & $7,130,768$ & \\
DNA coding region (bp) & $6,434,142$ & 90.23 \\
DNA G+C content (bp) & $3,087,622$ & 43.30 \\
Number of replicons & 1 & \\
Extra chromosomal element & 0 & 100 \\
Total genes & 5,845 & 1.01 \\
RNA genes & 59 & 98.99 \\
Protein-coding genes & 5,786 & 53.22 \\
Genes with function prediction & 3,111 & 48.24 \\
Genes assigned to COGs & 2,820 & 7.44 \\
Genes with peptide signals & 435 & 7.80 \\
Genes with transmembrane helices & 456 & \\
\hline
\end{tabular}

a The total is based on either the size of the genome in base pairs or the total number of protein-coding genes in the annotated genome 
Table 5. Number of genes associated with the 25 general COG functional categories

\begin{tabular}{|c|c|c|c|}
\hline Code & Value & \%age $^{a}$ & Description \\
\hline$J$ & 156 & 2.66 & Translation \\
\hline A & 0 & 0 & RNA processing and modification \\
\hline $\mathrm{K}$ & 234 & 4.00 & Transcription \\
\hline $\mathrm{L}$ & 200 & 3.42 & Replication, recombination and repair \\
\hline $\mathrm{B}$ & 0 & 0 & Chromatin structure and dynamics \\
\hline $\mathrm{D}$ & 27 & 0.46 & Cell cycle control, mitosis and meiosis \\
\hline Y & 0 & 0 & Nuclear structure \\
\hline V & 107 & 1.83 & Defense mechanisms \\
\hline $\mathrm{T}$ & 240 & 4.22 & Signal transduction mechanisms \\
\hline M & 361 & 6.17 & Cell wall/membrane biogenesis \\
\hline$N$ & 5 & 0.08 & Cell motility \\
\hline Z & 0 & 0 & Cytoskeleton \\
\hline W & 0 & 0 & Extracellular structures \\
\hline$U$ & 65 & 1.11 & Intracellular trafficking and secretion \\
\hline $\mathrm{O}$ & 89 & 1.52 & $\begin{array}{l}\text { Posttranslational modification, protein turnover, chaper- } \\
\text { ones }\end{array}$ \\
\hline $\mathrm{C}$ & 168 & 2.87 & Energy production and conversion \\
\hline G & 369 & 6.31 & Carbohydrate transport and metabolism \\
\hline $\mathrm{E}$ & 212 & 3.62 & Amino acid transport and metabolism \\
\hline $\mathrm{F}$ & 73 & 1.25 & Nucleotide transport and metabolism \\
\hline $\mathrm{H}$ & 130 & 2.22 & Coenzyme transport and metabolism \\
\hline I & 87 & 1.48 & Lipid transport and metabolism \\
\hline $\mathrm{P}$ & 202 & 3.42 & Inorganic ion transport and metabolism \\
\hline Q & 47 & 0.80 & $\begin{array}{l}\text { Secondary metabolites biosynthesis, transport and ca- } \\
\text { tabolism }\end{array}$ \\
\hline $\mathrm{R}$ & 518 & 8.86 & General function prediction only \\
\hline $\mathrm{S}$ & 197 & 3.37 & Function unknown \\
\hline- & 2966 & 51.26 & Not in COGs \\
\hline
\end{tabular}

a The total is based on the total number of protein-coding genes in the annotated genome.

\section{Genome comparison with other}

\section{Bacteroides genomes}

Here, we compare the genome of $B$. timonensis with those of $B$. intestinalis, DSM 17393, $B$. cellulosilyticus DSM 14838, B. fragilis YCH46, $B$. vulgatus ATCC 8482, B. thetaiotaomicron VPI5482 , B. salanitronis DSM 18170, B. helcogenes $\mathrm{P}$ 36-108, B. finegoldii DSM 17565 and B. uniformis ATCC 8492. The draft genome of $B$. timonensis $(7.13 \mathrm{Mb})$ is larger than all other studied genomes (Table 6A). It also exhibits a higher $\mathrm{G}+\mathrm{C}$ content than all other genomes except $B$. salanitronis, $B$. helcogenes and $B$. uniformis (43.3, $46.4,44.7$ and 46.4\%, respectively). $B$. timonensis has a higher gene content $(5,786)$ than any other compared genome. The distribution of genes into COG categories was similar in all 10 compared genomes except in the $\mathrm{N}$ cate- gory (cell motility) for which $B$. fragilis, $B$. vulgatus, $B$. salanitronis, $B$. helcogenes and $B$. uniformis were underrepresented (Figure 7). In addition, B. timonensis shared 2,956, 3,081, $2,159,2,099,2,379,1,721,2,001,2,039$ and 2,268 orthologous genes with $B$. intestinalis, $B$. cellulosilyticus, $B$. fragilis, $B$. vulgatus, $B$. thetaiotaomicron, B. salanitronis, B. helcogenes, $B$. finegoldii and B. uniformis, respectively. Among compared genomes except $B$. timonensis, AGIOS values ranged from 70.16 between B. salitronis and B. cellulosilyticus to $88.16 \%$ between $B$. intestinalis and B. cellulosilyticus. When $B$. timonensis was compared to other species, AGIOS values ranged from 70.29 with $B$. salitronis to $93.61 \%$ with B. cellulosilyticus (Table 6B). 
Table 6A. Genomic comparison of B. timonensis with 9 other Bacteroides species ${ }^{\dagger}$.

\begin{tabular}{|c|c|c|c|c|}
\hline Species & Strain & $\begin{array}{l}\text { Genome acces- } \\
\text { sion } \\
\text { number }\end{array}$ & $\begin{array}{r}\text { Genome size } \\
(\mathrm{Mb}) \\
\end{array}$ & $G+C$ content \\
\hline B. timonensis & AP1 & CBVI010000000 & 7.13 & 43.3 \\
\hline & & NZ_ABJL000000 & & \\
\hline B. intestinalis & DSM 17393 & 00 & 6.05 & 42.8 \\
\hline B. cellulosilyticus & DSM 14838 & $\begin{array}{l}\text { NZ_ACCHOOOOO } \\
000\end{array}$ & 6.87 & 42.7 \\
\hline B. fragilis & YCH46 & NC_006347 & 5.28 & 43.2 \\
\hline B. vulgatus & ATCC 8482 & NC_009614 & 5.16 & 42.2 \\
\hline B. thetaiotaomicron & VPI-5482 & NC_004663 & 6.26 & 42.8 \\
\hline B. salanitronis & DSM 18170 & NC_015164 & 4.24 & 46.4 \\
\hline B. helcogenes & P 36-108 & NC_014933 & 4.0 & 44.7 \\
\hline B. finegoldii & DSM 17565 & $\begin{array}{l}\text { NZ_ABXI000000 } \\
00\end{array}$ & 4.89 & 42.9 \\
\hline B. uniformis & ATCC 8492 & AAYH00000000 & 4.72 & 46.4 \\
\hline
\end{tabular}

${ }^{\dagger}$ Species, Strain, GenBank accession number, genome size and G+C content of all compared genomes.

Table 6B. Genomic comparison of B. timonensis with 9 other Bacteroides species ${ }^{\dagger}$.

\begin{tabular}{|c|c|c|c|c|c|c|c|c|c|c|}
\hline & B. tim & B. int & B. cel & B. fra & B. vul & B. the & B. sal & B. hel & B. fin & B. uni \\
\hline B. tim & 5,786 & 2,956 & 3,081 & 2,159 & 2,099 & 2,379 & 1,721 & 2,001 & 2,039 & 2,268 \\
\hline B. int & 87.73 & 4,911 & 2,967 & 2,085 & 2,036 & 2,361 & 1,667 & 1,963 & 2,066 & 2,278 \\
\hline B. cell & 93.61 & 88.16 & 5,719 & 2,130 & 2,078 & 2,380 & 1,655 & 1,990 & 2,017 & 2,231 \\
\hline B. fra & 73.76 & 74.43 & 73.92 & 4,184 & 1,927 & 2,174 & 1,517 & 1,893 & 1,880 & 1,995 \\
\hline B. vul & 71.91 & 71.74 & 71.48 & 71.87 & 4,066 & 2,100 & 1,638 & 1,743 & 1,859 & 1,898 \\
\hline B. the & 73.99 & 74.65 & 73.87 & 75.42 & 72.21 & 4,778 & 1,601 & 1,891 & 2,191 & 2,039 \\
\hline B. sal & 70.29 & 70.65 & 70.16 & 70.35 & 72.18 & 70.50 & 3,553 & 1,466 & 1,580 & 1,584 \\
\hline B. hel & 76.40 & 76.51 & 76.41 & 74.15 & 71.62 & 73.64 & 70.68 & 3,244 & 1,703 & 1,930 \\
\hline B. fin & 74.28 & 75.01 & 74.45 & 75.72 & 72.22 & 81.24 & 70.77 & 73.99 & 4,485 & 1,920 \\
\hline B. uni & 77.08 & 76.83 & 76.80 & 74.25 & 72.45 & 74.36 & 71.32 & 79.37 & 74.77 & 4,663 \\
\hline
\end{tabular}

† numbers of orthologous proteins shared between genomes (above diagonal), AGIOS values (below diagonal) and numbers of proteins per genome (bold numbers).

B. tim $_{\text {B }}$ B. timonensis, B. int $=$ B. intestinalis, B. cel = B. cellulosilyticus, B. fra = B. fragilis, B. vul $=B$. vulgatus, $B$. the $=B$. thetaiotaomicron, B. sal = B. salanitronis, B. hel = B. helcogenes, $B$. uni $=B$. uniformis, $B$. fin = B. finegoldii. 




COG categories

Figure 7. Distribution of predicted genes of $B$. timonensis and 9 other Bacteroides species into COG categories. B. uni $=B$. uniformis, B. fin $=B$. finegoldii, B. hel $=B$. helcogenes, B. sal $=B$. salanitronis, B. the $=B$. thetaiotaomicron, $\mathrm{B} . \mathrm{vul}=\mathrm{B}$. vulgatus, $\mathrm{B}$. fra $=B$. fragilis, $\mathrm{B}$. cel $=B$. cellulosilyticus, $\mathrm{B}$. int $=B$. intestinalis, B. tim $=$ B. timonensis.

\section{Conclusion}

On the basis of phenotypic, phylogenetic and genomic analyses (taxono-genomics), we formally propose the creation of Bacteroides timonensis sp. nov. that contains strain $\mathrm{AP} 1^{\mathrm{T}}$. This strain was isolated from the fecal flora of a 21-year-old woman who suffered from severe anorexia nervosa.

\section{Description of $B$. timonensis sp. nov.}

Bacteroides timonensis (tim.o.nen'sis. L. masc. adj. timonensis, of Timone, the name of the hospital where strain $\mathrm{AP} 1^{\mathrm{T}}$ was first cultivated).

Colonies are translucent and $0.3 \mathrm{~mm}$ in diameter on blood-enriched Columbia agar. Cells are rodshaped with a mean diameter of $0.88 \mu \mathrm{m}$. Optimal growth is achieved anaerobically, although the strain is able to grow under microaerophilic conditions, and weakly with $5 \% \mathrm{CO}_{2}$. Growth occurs between $25^{\circ} \mathrm{C}$ and $37^{\circ} \mathrm{C}$, with optimal growth at $37^{\circ} \mathrm{C}$. Cells stain Gram-negative and are not motile. Positive reactions for catalase, arginine dihydrolase, $\alpha$-galactosidase, $\beta$ galactosidase, $\alpha$-glucosidase, $\beta$-glucosidase, $\alpha-$ arabinosidase, $\mathrm{N}$-acetyl- $\beta$-glucosaminidase, glutamic acid decarboxylase, $\alpha$-fucosidase, nitrate reduction, indole production, alkaline phosphatase, proline arylamidase, leucyl glycine arylamidase, alanine arylamidase, glutamyl glutamic acid arylamidase, and fermentation of mannose and raffinose.

Weak activities are observed for glycine arylamidase and serine arylamidase. Negative reactions are obtained for urease, $\beta$ galctosidase-6-phosphatase, $\beta$-glucuronidase, arginine arylamidase, phenylalanine arylamidase, leucine arylamidase, pyroglutamic acid arylamidase, tyrosine arylamidase and histidine arylamidase. Using an API 50CH strip (Biomerieux), strain $\mathrm{AP} 1^{\mathrm{T}}$ is asaccharolytic. Cells are susceptible to susceptible to amoxicillinclavulanate, ceftriaxone, imipenem, trimethoprim-sulfamethoxazole, metronidazole and doxycycline but resistant to amoxicillin, vancomycin and gentamicin.

The 16S rRNA and genome sequences are deposited in GenBank under accession numbers JX041639 and CBVI000000000, respectively. The $\mathrm{G}+\mathrm{C}$ content of the genome is $43.3 \%$. The habitat of the organism is the digestive tract. The type strain AP1 $1^{\mathrm{T}}$ (= CSUR P194 = DSMZ 26083) was isolated from the fecal flora of a French Caucasoid female who suffered from a severe restrictive form of anorexia nervosa. This strain has been found in Marseille, France. 


\section{Acknowledgements}

The authors thank the Xegen Company (www.xegen.fr) for automating the genomic an-

\section{References}

1. Lagier JC, Armougom F, Million M, Hugon $\mathrm{P}$, Pagnier I, Robert C, Bittar F, Fournous G, Gimenez G, Maraninchi M, et al. Microbial culturomics: paradigm shift in the human gut microbiome study. Clin Microbiol Infect 2012; 18:1185-1193. PubMed

2. Tindall BJ, Rosselló-Móra R, Busse HJ, Ludwig W, Kämpfer P. Notes on the characterization of prokaryote strains for taxonomic purposes. Int J Syst Evol Microbiol 2010; 60:249-266. PubMed http://dx.doi.org/10.1099/ijs.0.016949-0

3. Stackebrandt E, Ebers J. Taxonomic parameters revisited: tarnished gold standards. Microbiol Today 2006; 33:152-155.

4. Wayne LG, Brenner DJ, Colwell PR, Grimont PAD, Kandler O, Krichevsky MI, Moore LH, Moore WEC, Murray RGE, Stackebrandt E, et al. Report of the ad hoc committee on reconciliation of approaches to bacterial systematic. Int J Syst Bacteriol 1987; 37:463-464. http://dx.doi.org/10.1099/00207713-37-4-463

5. Rossello-Mora R. DNA-DNA Reassociation Methods Applied to Microbial Taxonomy and Their Critical Evaluation. In: Stackebrandt E (ed), Molecular Identification, Systematics, and population Structure of Prokaryotes. Springer, Berlin, 2006; p. 23-50.

6. Welker M, Moore ER. Applications of wholecell matrix-assisted laser-desorption/ionization time-of-flight mass spectrometry in systematic microbiology. Syst Appl Microbiol 2011; 34:211. PubMed http://dx.doi.org/10.1016/j.syapm.2010.11.013

7. Kokcha S, Mishra AK, Lagier JC, Million M, Leroy Q, Raoult D, Fournier PE. Noncontiguous finished genome sequence and description of Bacillus timonensis sp. nov. Stand Genomic Sci 2012; 6:346-355. PubMed http://dx.doi.org/10.4056/sigs.2776064

8. Ramasamy D, Mishra AK, Lagier JC, Padhmanabhan R, Rossi-Tamisier M, Sentausa E, Raoult D, Fournier PE. A polyphasic strategy incorporating genomic data for the taxonomic description of new bacterial species. Int / Syst Evol Microbiol 2013; 64:384-391. PubMed http://dx.doi.org/10.1099/ijs.0.057091-0

9. Lagier JC, El Karkouri K, Nguyen TT, Armougom $F$, Raoult D, Fournier PE. Non-contiguous finished genome sequence and description of Anaerococcus senegalensis sp. nov. Stand Ge- notation process. This study was funded by the Mediterranee-Infection Foundation.

nomic Sci 2012; 6:116-125. PubMed

http://dx.doi.org/10.4056/sigs.2415480

10. Mishra AK, Gimenez G, Lagier JC, Robert C, Raoult D, Fournier PE. Non-contiguous finished genome sequence and description of Alistipes senegalensis sp. nov. Stand Genomic Sci 2012; 6:304-314. http://dx.doi.org/10.4056/sigs.2625821

11. Lagier JC, Armougom F, Mishra AK, Ngyuen TT, Raoult D, Fournier PE. Non-contiguous finished genome sequence and description of Alistipes timonensis sp. nov. Stand Genomic Sci 2012; 6:315-324. PubMed http://dx.doi.org/10.4056/sigs.2685971

12. Mishra AK, Lagier JC, Robert C, Raoult D, Fournier PE. Non-contiguous finished genome sequence and description of Clostridium senegalense sp. nov. Stand Genomic Sci 2012; 6:386-395. PubMed

13. Mishra AK, Lagier JC, Robert C, Raoult D, Fournier PE. Non-contiguous finished genome sequence and description of Peptoniphilus timonensis sp. nov. Stand Genomic Sci 2012; 7:1-11. PubMed http://dx.doi.org/10.4056/sigs.2956294

14. Mishra AK, Lagier JC, Rivet R, Raoult D, Fournier PE. Non-contiguous finished genome sequence and description of Paenibacillus senegalensis sp. nov. Stand Genomic Sci 2012; 7:70-81. PubMed http://dx.doi.org/10.4056/sigs.3056450

15. Lagier JC, Gimenez G, Robert C, Raoult D, Fournier PE. Non-contiguous finished genome sequence and description of Herbaspirillum massiliense sp. nov. Stand Genomic Sci 2012; 7:200-209. PubMed

16. Kokcha S, Ramasamy D, Lagier JC, Robert C, Raoult D, Fournier PE. Non-contiguous finished genome sequence and description of Brevibacterium senegalense sp. nov. Stand Genomic Sci 2012; 7:233-245. PubMed http://dx.doi.org/10.4056/sigs.3256677

17. Ramasamy D, Kokcha S, Lagier JC, N'Guyen TT, Raoult D, Fournier PE. Non-contiguous finished genome sequence and description of Aeromicrobium massilense sp. nov. Stand Genomic Sci 2012; 7:246-257. PubMed http://dx.doi.org/10.4056/sigs.3306717

18. Lagier JC, Ramasamy D, Rivet R, Raoult D, Fournier PE. Non-contiguous finished genome 
sequence and description of Cellulomonas massiliensis sp. nov. Stand Genomic Sci 2012; 7:258-270. PubMed http://dx.doi.org/10.4056/sigs.3316719

19. Lagier JC, Karkouri K, Rivet R, Couderc C, Raoult D, Fournier PE. Non contiguous-finished genome sequence and description of Senegalemassilia anaerobia gen. nov., sp. nov. Stand Genomic Sci 2013; 7:343-356. PubMed http://dx.doi.org/10.4056/sigs.3246665

20. Mishra AK, Hugon P, Nguyen TT, Robert C, Couderc C, Raoult D, Fournier PE. Non contiguous-finished genome sequence and description of Peptoniphilus obesi sp. nov. Stand Genomic Sci 2013; 7:357-369. PubMed http://dx.doi.org/10.4056/sigs.32766871

21. Mishra AK, Lagier JC, Nguyen TT, Raoult D, Fournier PE. Non contiguous-finished genome sequence and description of Peptoniphilus senegalensis sp. nov. Stand Genomic Sci 2013; 7:370-381. PubMed http://dx.doi.org/10.4056/sigs.3366764

22. Lagier JC, Karkouri K, Mishra AK, Robert C, Raoult D, Fournier PE. Non contiguous-finished genome sequence and description of Enterobacter massiliensis sp. nov. Stand Genomic Sci 2013; 7:399-412. PubMed http://dx.doi.org/10.4056/sigs.3396830

23. Hugon P, Ramasamy D, Rivet R, Raoult D, Fournier PE. Non contiguous-finished genome sequence and description of Alistipes obesi sp. nov. Stand Genomic Sci 2013; 7:427-439. PubMed http://dx.doi.org/10.4056/sigs.3336746

24. Hugon P, Mishra AK, Nguyen TT, Raoult D, Fournier PE. Non-contiguous finished genome sequence and description of Brevibacillus massiliensis sp. nov. Stand Genomic Sci 2013; 8:1-14. PubMed http://dx.doi.org/10.4056/sigs.3466975

25. Mishra AK, Hugon P, Nguyen TT, Raoult D, Fournier PE. Non contiguous-finished genome sequence and description of Enorma massiliensis gen. nov., sp. nov., a new member of the Family Coriobacteriaceae. Stand Genomic Sci 2013; 8:290-305. PubMed http://dx.doi.org/10.4056/sigs.3426906

26. Ramasamy D, Lagier JC, Gorlas A, Raoult D, Fournier PE. Non contiguous-finished genome sequence and description of Bacillus massiliosenegalensis sp. Nov. Stand Genomic Sci 2013; 8:264-278. PubMed http://dx.doi.org/10.4056/sigs.3496989

27. Ramasamy D, Lagier JC, Nguyen TT, Raoult D, Fournier PE. Non contiguous-finished genome sequence and description of Dielma fastidiosa gen. nov., sp. nov., a new member of the Fami- ly Erysipelotrichaceae. Stand Genomic Sci

2013; 8:336-351. PubMed

http://dx.doi.org/10.4056/sigs.3567059

28. Mishra AK, Pfleiderer A, Lagier JC, Robert C, Raoult D, Fournier PE. Non contiguous-finished genome sequence and description of Bacillus massilioanorexius sp. nov. Stand Genomic Sci 2013; 8:465-479. PubMed http://dx.doi.org/10.4056/sigs.4087826

29. Hugon P, Ramasamy D, Robert C, Couderc C, Raoult D, Fournier PE. Non-contiguous finished genome sequence and description of Kallipyga massiliensis gen. nov., sp. nov., a new member of the family Clostridiales Incertae Sedis XI. Stand Genomic Sci 2013; 8:500-515. PubMed http://dx.doi.org/10.4056/sigs.4047997

30. Padmanabhan R, Lagier JC, Dangui NPM, Michelle C, Couderc C, Raoult D, Fournier PE. Non-contiguous finished genome sequence and description of Megasphaera massiliensis. Stand Genomic Sci 2013; 8:525-538. PubMed http://dx.doi.org/10.4056/sigs.4077819

31. Mishra AK, Edouard S, Dangui NPM, Lagier JC, Caputo A, Blanc-Tailleur C, Ravaux I, Raoult D, Fournier PE. Non-contiguous finished genome sequence and description of Nosocomiicoccus massiliensis sp. nov. Stand Genomic Sci 2013; 9:205-219. PubMed http://dx.doi.org/10.4056/sigs.4378121

32. Mishra AK, Lagier JC, Robert C, Raoult D, Fournier PE. Genome sequence and description of Timonella senegalensis gen. nov., sp. nov., a new member of the suborder Micrococcineae. Stand Genomic Sci 2013; 8:318-335. PubMed http://dx.doi.org/10.4056/sigs.3476977

33. Keita MB, Diene SM, Robert C, Raoult D, Fournier PE. Non contiguous-finished genome sequence and description of Bacillus massiliogorillae sp. nov. Stand Genomic Sci 2013; 9:93-105. PubMed http://dx.doi.org/10.4056/sigs.4388124

34. Mediannikov O, El Karkouri K, Robert C, Fournier PE, Raoult D. Non contiguous-finished genome sequence and description of Bartonella florenciae sp. nov. Stand Genomic Sci 2013; 9:185-196. PubMed http://dx.doi.org/10.4056/sigs.4358060

35. Lo Cl, Mishra AK, Padhmanabhan R, Samb Ba B, Gassama Sow A, Robert C, Couderc C, Faye $\mathrm{N}$, Raoult D, Fournier PE, Fenollar F. Non contiguous-finished genome sequence and description of Clostridium dakarense sp. nov. Stand Genomic Sci 2013; 9:14-27. PubMed http://dx.doi.org/10.4056/sigs.4097825

36. Mishra AK, Hugon $P$, Robert C, Raoult D, Fournier PE. Non contiguous-finished genome se- 
Ramasamy et al.

quence and description of Peptoniphilus grossensis sp. nov. Stand Genomic Sci 2012; 7:320-330. PubMed

37. Mediannikov O, El Karkouri K, Diatta G, Robert C, Fournier PE, Raoult D. Non contiguousfinished genome sequence and description of Bartonella senegalensis sp. nov. Stand Genomic Sci 2013; 8:279-289. PubMed http://dx.doi.org/10.4056/sigs.3807472

38. Garrity GM, Holt JG. Taxonomic Outline of the Archaea and Bacteria. In: Garrity GM, Boone DR, Castenholz RW (eds), Bergey's Manual of Systematic Bacteriology, Second Edition, Volume 1, Springer, New York, 2001, p. 155-166.

39. Eckburg PB, Bik EM, Bernstein CN, Purdom E, Dethlefsen L, Sargent M, Gill SR, Nelson KE, Relman DA. Diversity of the human intestinal microbial flora. Science 2005; 308:1635-1638. $\underline{\text { PubMed }}$

http://dx.doi.org/10.1126/science. 1110591

40. List of Prokaryotic names with standing nomenclature (LPSN). http://www.bacterio.cict.fr.

41. Smith CJ, Rocha ER, Paster BJ. 2005. The medically important Bacteroides spp. in health and disease. In The Prokaryotes, an evolving electronic resource for the microbiological community, Release 3.19 (18.3.2005) (http://141-150157-117:8080/prokPUB/index.htm). Edited by M. Dworkin. New York: Springer.

42. Finegold SM, George WL. 1989. Anaerobic Infections in Humans. San Diego: Academic Press.

43. Field D, Garrity G, Gray T, Morrison N, Selengut J, Sterk P, Tatusova T, Thomson N, Allen MJ, Angiuoli SV, et al. The minimum information about a genome sequence (MIGS) specification. Nat Biotechnol 2008; 26:541-547. PubMed http://dx.doi.org/10.1038/nbt1360

44. Woese CR, Kandler O, Wheelis ML. Towards a natural system of organisms: proposal for the domains Archaea, Bacteria, and Eucarya. Proc Natl Acad Sci USA 1990; 87:4576-4579. PubMed http://dx.doi.org/10.1073/pnas.87.12.4576

45. Validation List No. 143. Int / Syst Evol Microbiol 2012; 62:1-4.

http://dx.doi.org/10.1099/ijs.0.039487-0

46. Krieg NR, Ludwig W, Euzéby J, Whitman WB. Phylum XIV. Bacteroidetes phyl. nov. In: Krieg NR, Staley JT, Brown DR, Hedlund BP, Paster BJ, Ward NL, Ludwig W, Whitman WB (eds), Bergey's Manual of Systematic Bacteriology, Second Edition, Volume 4, Springer, New York, 2011, p. 25.

47. Krieg NR. Class I. Bacteroidia class. nov. In: Krieg NR, Staley JT, Brown DR, Hedlund BP,
Paster BJ, Ward NL, Ludwig W, Whitman WB (eds), Bergey's Manual of Systematic Bacteriology, Second Edition, Volume 4, Springer, New York, 2011, p. 25.

48. Krieg NR. Order I. Bacteroidales ord. nov. In: Krieg NR, Staley JT, Brown DR, Hedlund BP, Paster BJ, Ward NL, Ludwig W, Whitman WB (eds), Bergey's Manual of Systematic Bacteriology, Second Edition, Volume 4, Springer, New York, 2011, p. 25.

49. Skerman VBD, McGowan V, Sneath PHA. Approved Lists of Bacterial Names. Int I Syst Bacteriol 1980; 30:225-420. http://dx.doi.org/10.1099/00207713-30-1-225

50. Pribram E. Klassification der Schizomyceten. Klassifikation der Schizomyceten (Bakterien), Franz Deuticke, Leipzig, 1933, p. 1-143.

51. Castellani A, Chalmers AJ. Genus Bacteroides Castellani and Chalmers, 1918. Manual of Tropical Medicine, Third Edition, Williams, Wood and Co., New York, 1919, p. 959-960.

52. Holdeman LV, Moore WEC. Genus I. Bacteroides Castellani and Chalmers 1919, 959. In: Buchanan RE, Gibbons NE (eds), Bergey's Manual of Determinative Bacteriology, Eighth Edition, The Williams and Wilkins Co., Baltimore, 1974 , p. 385-404.

53. Cato EP, Kelley RW, Moore WEC, Holdeman LV. Bacteroides zoogleoformans, Weinberg, Nativelle, and Prévot 1937) corrig. comb. nov.: emended description. Int / Syst Bacteriol 1982; 32:271-274.

http://dx.doi.org/10.1099/00207713-32-3-271

54. Shah HN, Collins MD. Proposal to restrict the genus Bacteroides (Castellani and Chalmers) to Bacteroides fragilis and closely related species. Int J Syst Bacteriol 1989; 39:85-87. http://dx.doi.org/10.1099/00207713-39-1-85

55. Ashburner M, Ball CA, Blake JA, Botstein D, Butler $\mathrm{H}$, Cherry JM, Davis AP, Dolinski K, Dwight SS, Eppig JT, et al. Gene ontology: tool for the unification of biology. The Gene Ontology Consortium. Nat Genet 2000; 25:25-29. PubMed http://dx.doi.org/10.1038/75556

56. 16S Yourself database. (http://www.mediterraneeinfection.com/article.php?larub=152\&titre=16syourself).

57. Eggerth $\mathrm{AH}$, Gagnon $\mathrm{BH}$. The Bacteroides of Human Feces. J Bacteriol 1933; 25:389-413. PubMed

58. Shah HN. 1992. The genus Bacteroides and related taxa. In The Prokaryotes, 2nd edn, pp. 3593-3607. Edited by Balows A, Truper HG, 
Dworkin M, Harder M \& Schleifer KH. New York: Springer.

59. Bakir MA, Kitahara M, Sakamoto M, Matsumoto M, Benno Y. Bacteroides intestinalis sp. nov., isolated from human faeces. Int I Syst Evol Microbiol 2006; 56:151-154. PubMed http://dx.doi.org/10.1099/ijs.0.63914-0

60. Robert C, Chassard C, Lawson PA, BernalierDonadille A. Bacteroides cellulosilyticus sp. nov., a cellulolytic bacterium from the human gut microbial community. Int I Syst Evol Microbiol 2007; 57:1516-1520. PubMed http://dx.doi.org/10.1099/ijs.0.64998-0

61. Johnson JL. Taxonomy of the Bacteroides I. Deoxyribonucleic acid homologies among Bacteroides fragilis and other saccharolytic Bacteroides species. Int I Syst Evol Microbiol 1978; 28:245-256.

62. Cato EP, Johnson JL. Reinstatement of species rank for Bacteroides fragilis, $B$. ovatus, $B$. distasonis, B. thetaiotaomicron, and B. vulgatus: Designation of Neotype Strains for Bacteroides fragilis (Veillon and Zuber) Castellani and Chalmers and Bacteroides thetaiotaomicron (Distaso) Castellani and Chalmers. Int J Syst Bacteriol 1976; 26:230-237. http://dx.doi.org/10.1099/00207713-26-2-230

63. Xu J, Bjursell MK, Himrod J, Deng S, Carmichael LK, Chiang HC, Hooper LV, Gordon JI. A genomic view of the human-Bacteroides thetaiotaomicron symbiosis. Science 2003; 299:2074-2076. PubMed http://dx.doi.org/10.1126/science.1080029

64. Lan PT, Sakamoto M, Sakata S, Benno Y. Bacteroides barnesiae sp. nov., Bacteroides salanitronis sp. nov. and Bacteroides gallinarum sp. nov., isolated from chicken caecum. Int J Syst Evol Microbiol 2006; 56:2853-2859. PubMed http://dx.doi.org/10.1099/ijs.0.64517-0

65. Benno Y, Watabe J, Mitsuoka T. Bacteroides pyogenes sp. nov., Bacteroides suis sp. nov., and Bacteroides helcogenes sp. nov., New Species from Abscesses and Feces of Pigs. Syst Appl Microbio 1983; 14:396-407.

66. Pati A, Gronow S, Zeytun A, Lapidus A, Nolan M, Hammon N, Deshpande S, Cheng JF, Tapia $\mathrm{R}$, Han $\mathrm{C}$, et al. Complete genome sequence of Bacteroides helcogenes type strain (P 36-108). Stand Genomic Sci 2011; 4:45-53. PubMed http://dx.doi.org/10.4056/sigs.1513795

67. Bakir MA, Kitahara M, Sakamoto M, Matsumoto M, Benno Y. Bacteroides finegoldii sp. nov., isolated from human faeces. Int I Syst Evol Microbiol 2006; 56:931-935. PubMed http://dx.doi.org/10.1099/ijs.0.64084-0
68. Seng P, Drancourt M, Gouriet F, La SB, Fournier $\mathrm{PE}$, Rolain JM, Raoult D. Ongoing revolution in bacteriology: routine identification of bacteria by matrix-assisted laser desorption ionization time-of-flight mass spectrometry. Clin Infect Dis 2009; 49:543-551. PubMed http://dx.doi.org/10.1086/600885

69. Prodigal. http://prodigal.ornl.gov/

70. Benson DA, Karsch-Mizrachi I, Clark K, Lipman DJ, Ostell J, Sayers EW. GenBank. Nucleic Acids Res 2012; 40:D48-D53. PubMed http://dx.doi.org/10.1093/nar/gkr1202

71. Lowe TM, Eddy SR. tRNAscan-SE: a program for improved detection of transfer RNA genes in genomic sequence. Nucleic Acids Res 1997; 25:955-964. PubMed http://dx.doi.org/10.1093/nar/25.5.0955

72. Lagesen K, Hallin P, Rodland EA, Staerfeldt HH, Rognes T, Ussery DW. RNAmmer: consistent and rapid annotation of ribosomal RNA genes. Nucleic Acids Res 2007; 35:3100-3108. PubMed http://dx.doi.org/10.1093/nar/gkm160

73. Bendtsen JD, Nielsen H, von Heijne G, Brunak S. Improved prediction of signal peptides: SignalP 3.0. J Mol Biol 2004; 340:783-795. PubMed http://dx.doi.org/10.1016/j.jmb.2004.05.028

74. Krogh A, Larsson B, von Heijne G, Sonnhammer EL. Predicting transmembrane protein topology with a hidden Markov model: application to complete genomes. J Mol Biol 2001; 305:567-580. PubMed http://dx.doi.org/10.1006/jmbi.2000.4315

75. Zhou Y, Liang Y, Lynch KH, Dennis JJ, Wishart DS. PHAST: a fast phage search tool. Nucleic Acids Res 2011; 39:W347-W352. PubMed http://dx.doi.org/10.1093/nar/gkr485

76. Aziz RK, Bartels D, Best AA, Dejongh M, Disz T, Edwards RA, Formsma K, Gerdes S, Glass EM, Kubal M, et al. The RAST Server: rapid annotations using subsystems technology. BMC Genomics 2008; 9:75. PubMed http://dx.doi.org/10.1186/1471-2164-9-75

77. Rutherford K, Parkhill J, Crook J, Horsnell T, Rice P, Rajandream MA, Barrell B. Artemis: sequence visualization and annotation. Bioinformatics 2000; 16:944-945. PubMed http://dx.doi.org/10.1093/bioinformatics/16.10. 944

78. Carver T, Thomson N, Bleasby A, Berriman M, Parkhill J. DNAPlotter: circular and linear interactive genome visualization. Bioinformatics 2009; 25:119-120. PubMed http://dx.doi.org/10.1093/bioinformatics/btn578 
Ramasamy et al.

79. Darling AC, Mau B, Blattner FR, Perna NT. Mauve: multiple alignment of conserved genomic sequence with rearrangements. Genome Res 2004; 14:1394-1403. PubMed http://dx.doi.org/10.1101/gr.2289704

80. Lechner M, Findeib S, Steiner L, Marz M,
Stadler PF, Prohaska SJ. Proteinortho: Detection of (Co-)orthologs in large-scale analysis. BMC Bioinformatics 2011; 12:124. PubMed http://dx.doi.org/10.1186/1471-2105-12-124 